\title{
THE CAUSES OF LOSING TRUST IN THE GOVERNMENT IN RECENT YEARS IN ALBANIA
}

\author{
Anisa Proda ${ }^{1}$
}

\begin{abstract}
As the last country in Europe to overthrow the communist regime, Albania has much to achieve in the legal system to build a full democracy. A government should be relied upon to create the necessary reforms to move a country out of transition. The governmental structure can either accelerate or prevent the country's transition towards a market economy. The other pillar of society that reflects institutional performance is the country's citizens. Trust is a factor that connects citizens with institutions. The main purpose of this research is to identify causes for citizens to lose their confidence in public institutions. The analysis, supported by quantitative data, aims to show the level of trust that citizens bestow to the most important Albanian public institutions. An Institution for Democracy and Mediation poll and this study's results of meetings with focus groups were used to illustrate the public's confidence in the governmental institutions, and to explore the causes of the citizen's attitude towards the public institutions and their service in Albania.
\end{abstract}

UDC Classification: 323.2, DOI: http://dx.doi.org/10.12955/cbup.v4.783

Keywords: trust, government, citizens, institutions, social capital.

\section{Introduction}

As the last country in Europe to overthrow the communist regime, Albania still has much to achieve in the legal system to build a full democracy. Many societies pass from a centralized to a market economy through an intermediate process, known as a transition. This intermediate phase serves to transform the political and economic system to satisfy the needs of the market economy (Bellova, 2014). The basic policies for a transition for all post-communist countries have an identical economic structure. They were designed by the new governments, who were helped by international organizations, such as the International Monetary Fund, the World Bank, and the European Bank of Reconstruction and Development. Despite having a pluralistic political system or a balanced separation of the three powers, the political regime is still considered a hybrid democracy (Freedom House, 2015). The number of countries classified as the 'worst' in the 'Nations in Transition' report has doubled over the last decade.

The specter of the indicators that measure the quality of governance has expanded because of the increasing role that institutional factors play in the economic growth performance. However, how to quantitatively determine the qualitative indicators that measure the governmental quality is not well understood. Based on the World Bank's definition of governance, institutions need to support the private market. On one hand, the governance functions are the same as the market economy's; on the other hand, it requires the State to secure the appropriate environment for implementing reforms and accelerating the transition. The lack of institutional efficiency has been referred to as an overly long transition from a centralized system to a pluralistic democracy and market economy. Institutions are not the only parties to operate on barren ground. The realized governmental forms have been based on a number of formal and informal institutional mechanisms that have lead in the creation and implementation of reforms (North, 1990).

Concrete governmental structure can accelerate or obstruct a transition towards a market economy for various countries. A country's citizens form another important pillar that reflects the country's institutional performance. Trust connects citizen with institutions. More and more social scientists use trust as a basic concept to explain the different cooperation levels in different social and political environments. Not only should people know each other, to cooperate, to achieve their goals, but also they should trust each other and have confidence that they are not subject to abuse or deceit (Field,

\footnotetext{
${ }^{1}$ Anisa Proda, European University of Tirana, Tirana, Albania, info@ uet.edu.al
} 
2003). Thus, literature upholds the concept of trust. Recent studies have shown a decrease in the level of trust that people bestow to public institutions (Lame \& Papa, 2015).

The central research question aims to understand why citizens have lost confidence in the public institutions of Albania.

\section{Methodology}

The quality of governance is important, but is difficult to measure it for these reasons:

First, in measuring citizens' trust, their perception is important because their actions are based on their impressions and points of view. The analysis involved quantitative data (as percentages) to show the level of trust that citizens bestowed on the most important Albanian public institutions during 2015 . The Organization for Economic Co-operation and Development (OECD) identified six areas where governments can create and strengthen citizens' trust: reliability, accountability, sincerity, better rules, integrity, and all-inclusive policies. These areas served as a starting point and were an integral part of this paper. The study's purpose was to understand the perspective and thoughts of the Albanian society about these important issues. A survey was conducted on a national level in 2013 by the Institution for Democracy and Mediation (IDM) within the 'Advocacy for Open Governance' project. The IDM opinion poll gathered data from 1600 citizens in 61 civic centers through a quota method of sampling. This sample involved citizens of different age groups, from 18 to 65 years. The survey purpose was to obtain the opinion of citizens along with comprehensive social-demographic data, such as levels of education from primary to university education; income status, from low to high; employment status, such as self-employed, employed, unemployed, or student.

Mostly, the IDM study provided descriptive relational statistics of the situation. This present study developed 61 focus groups in each of the local units in which an opinion poll was performed.

Each focus group had five respondents who were chosen based on the demographic parameters of the IDM study. The focus groups were developed during March, 2016.

\section{Researching the Literature on the Concept of Public Trust in the Government}

Regarding the problems of drafting, implementing, and supporting the government's policies, the political institutions of a country play a dominant role. They determine the involvement scale of different parties in the political process, economic reforms, and also give form to the behavior of different parties. A governmental structure can affect the interests and incentives of politicians, legislators, bureaucrats, and private agents. In addition, it can determine the way citizens relate to each other and government officers.

Trusting the government means that citizens have faith in "the government's actions to do what is right and what is perceived as impartial" (Easton, 1965, p.?).

According to the OECD (n.d.), "trusting public institutions is important for the success of many public policies, programs and rules that depend on the cooperation between citizens and how much they respect these. Lack of trust compromises the citizens' and businesses' will to answer to the policies, which obstacles further stable development".

Trust includes taking risks as one parties action can effectively influence the other, but both share concerns, ideas, and problems. Trust can be applied in the "institutional factory" (Misztal, 1996). Putnam (1993) argued that having trust in the community allowed democracy to succeed in northern Italy. Trust is considered a public benefit that is easily achieved and established through the social system. Knowing the limitation of the rational choice theory, as not always providing the best instrument for decision making for both governments and citizens, Elster (1989) considered that the rational choice theory should be enriched with further analysis of social norms that contribute to social stability and cooperation.

$\mathrm{Fu}(2004$, p. 14) wrote the following in their thesis 'Social Capital, and Organizational Effectiveness': 
When seen as a characteristic or property of individuals, trust is a personality variable, thereby emphasis on individual characteristics like feelings, emotions, and values should be placed (Wolfe, 1976). A second perspective regards trust as a collective attribute that. On collective level, if an individual does not trust an agency or an organization to which he is connected, then he cannot fulfill an agreement (Dasgupta, 1988).

Researchers say that trust is hard to be created on purpose. Fu (2004, p. 15) went on to say:

Coleman suggests that if we talk about rational human beings, trust can only be produced into small, tight, informal and homogeneous networks, which are able to impose normative sanctions (Coleman, 1990). Granovetter (1985) believes that trust is generated when agreements are being secured by a structure larger than personal relations or social networks (pp. 488-493).

$\mathrm{Fu}(2004$, p. 33) also wrote: "Williams (1988) argues that moral principles, together with a general self-regulating and self-preserving structure, may develop and maintain trust in broader society" and that "Social structure is important not only for making social capital, but also for producing the trust itself. Social capital in all its forms found in the community, can also generate trust" (p. 16).

However, according to Fu (2004, p. 21), "Woolcock (1998) has argued that definitions of social capital should focus primarily on resources rather than consequences." Fu (2004, p. 5) also stated:

Bourdieu has argued that capital exists in three fundamental forms: economic capital that can be directly convertible into money and institutionalized in the form of property rights; cultural capital that may be convertible into economic capital and institutionalized in the form of educational qualification; and social capital, made up of social obligation that can be convertible into economic capital and institutionalized in the form of a title of nobility (Bourdieu, 1986, 243).

Putnam (1993) argued that social trust might arise from mutual norms. Trust should be embodied into the social institutions and cannot be fully understood without considering the influence of social institutions in the duties of human beings. Fukuyama argued that trust is a characteristic of the systems. He stated that the welfare of the nations, as well as their ability to compete, is conditioned by a single cultural characteristic: the level of inherited trust in society. Farrell and Knight (2003) suggested that institutions create rules and incentives for people to behave reliably, and feed on trust this way. Moreover, institutions distribute information about the expected behaviors to influence social thoughts regarding trust. David Easton (1965) defined trust as having a positive perception about an individual's or an organization's behavior. It is subjective and reflects the 'spectator's eyes' on matters that influence behavior.

The literature on social capital suggests a type of stagnation, regarding the concept of trust. According to $\mathrm{Fu}$ (2004), there are two cases that create confusion about trust, being 1) part of the social capital as reflected by researchers, such as, Coleman (1988), Putnam (1993), and Fukuyama (1995), and 2) a product, a consequence of the social capital, as proposed by Woolcock (1998) and Field (2003). Most literature on social capital is focused on the individual (Baker, 2000), on the nation (Putnam, 1993), or on the region (Fukuyama, 1995). The importance of trust has been widely accepted, but rarely analyzed. Gambetta (1988) argued that researchers considered it a fundamental ingredient, an unavoidable dimension of social interaction, that facilitates movement forward and dealing with unsolved issues (p. ii). Luhmann (1988) accepted that trust had never been a central topic of sociology. Fu (2004, p. 3) wrote that "Dasgupta (2000) argues that "It's not easy to model a connection between the personal group and institutional trust". However, we should study this connection if we want to understand the ideal social capital (p. 333)".

"Trust is found in different contests such as in the family, between friends, colleagues, organization that we take part in, even institutions to which we relate" (Fu, 2004, p.?).

For trust to be meaningful and suitable as a concept, it needs to be viewed in context. The trust an individual has for family members differs to that which they hold for organizations. Trust can be viewed as an element arising with roles, rules, and structured organizational relationships (McCauley 
\& Kuhnert, 1992). Robert Putnam has been eminent in recognizing the concept of social capital. He started his profession studying the performance of the regional administration between northern and southern Italy (Putnam, 1993). Trust was one of the features of social organization that improved cooperation and coordinated actions (Putnam, 1993, in Fu, 2004, p. 8). After studying the American civil society, Putnam modified his concept, describing it as a feature of social living that allowed people to act more effectively to achieve common goals (Putnam 1995, in Fu, 2004, p. 8). Putnam considered trust as a fundamental element that arises from the norms that bind the social network. Similarly, Fukuyama analyzed the connection between trust, social capital, and the success of the international economy (Fukuyama, 1999). Coleman (1988) confirmed that a mutual trust system is an important form of social capital, on which to base duties and future expectations. Nahapiet and Goshal (1998) considered trust as a key aspect in the dimension of social capital relationships. These different but, nevertheless, connected perceptions of the relationship between trust and social capital are partly a result of the close relation between the resources of trust and resources of social capital (Adler \& Kwon, 2000). Putnam (1993) argued that strong networks inside a community feed mutual norms, enable easy communication, and evoke trust, which encourages citizen cooperate for mutual benefits. Adler and Kwon (2000) argued that formal institutions and rules, which give form to the network and influence beliefs, also have a strong effect on social capital. Governments that take care of citizens' needs are a key factor in the settlement of formal rules and institutions. Levi (1996) argued that governments offer more than support to its citizens, as they also affect the civic behavior in a way that increases or decreases the trust in the government itself (p. 51).

\section{Clarifying Measurement and Qualitative Findings of Focus-Groups}

The IDM opinion poll had the purpose of identifying the public level of trust in the governmental institutions, whereas the focus-groups were aimed at exploring the cause of the citizens' attitude towards public institutions' work and service in Albania.

During the survey, more than $50 \%$ of the respondents did not express trust in most of the Albanian public institutions. Generally, they required more transparency about the use of finances.

Researchers noticed that although trust in public institutions was decreased, citizens had some faith in security institutions of North Atlantic Treaty Organization (NATO), the European Union (UE) and the police, which had a boost in 3 to 5\% trust levels; while $7 \%$ increase in trust was attributed to religious institutions.

One of the qualitative findings of the focus-groups was the evaluation of the performance of public institutions, classified in central and sectional level as a direct indicator of the quality of governance. Institutional obstacles towards business are an important part of the functioning of each institution. The characteristics of the investment climate within a country are related to the restrictions caused by these political and institutional obstacles on the performance of the firms. Corruption was considered one of the most widespread forms of institutional restrictions. Conventionally, it was defined as the exploitation of public power for private benefits. Regarding the dimensions of governance on a macro level, corruption was also viewed on this level, reflecting the effect of its different forms at a national level. The survey of the IDM discovered that citizens required transparent policy, all-inclusive processes, and responsibility mechanisms (Lame \& Papa, 2015).

According to the focus-groups findings, there was a large gap between what the political elite lectured every day and what citizens truly believed. The IDM survey was repeated regularly during the three years, and showed 74\% of Albanians believed more in international institutions, such as, NATO and the UE, than in their own institutions. These international institutions were considered as preventive and resolvers of the crises; they were more reliable; and they guaranteed the performance of public institutions in Albania. According to the respondents of the focus-groups in this study, international institutions monitor local institutions and criticize these when procedures are unsuccessful. Some respondents said that because Albania had been seeking, at any cost, to become a member of the UE 
and NATO some years previously, the international institutions have a better governmental performance.

The IDM survey showed that political parties had the lowest level of citizens' trust (19\%). According to the focus-groups, political parties are clienteles; they do not allow the government to operate independently and often interfere in government work. Also, the electorate was manipulated and 'bought' by exploiting the high level of unemployment and poverty in Albania; and political parties do not respect their own statutes, but promote 'suspicious' people that have no relation with the base and have no membership or activism past. Occasionally, these people are completely disconnected from the electorate and have no merit to warrant promotion.

According to the IDM survey, the sampled citizens had a low trust in the juridical system. The analysis of the responses in focus group study showed that the main cause for perceptions of high corruption in the juridical system, with its most widespread forms, are beliefs such as clientelism, nepotism, and bribery. Another indicator was that officials who were shown to be corrupt, need to be punished, and this failure reduced the level of trust to only $18 \%$. In terms of transparency, the respondents had a strong desire for the government to publicize tender procedures and public affairs contracts.

\section{Evaluating the Transparency}

This category included exchanging the parliamentary votes to approve laws that benefit private interests, trading presidential edicts to benefit private interests, misusing the Central Bank funds, trading court decisions connected to criminals or arbitrage, financing electoral campaigns, and political parties' interests by privates. According to the respondents, the competition for becoming part of the civil service were pre-determined and not transparent. The IDM survey showed how 76\% of the citizen respondents required technical and financial information about the government's activity. The respondents of the focus-groups affirmed that such information was not made public, and was often delayed, incomplete, or published on the official websites in an incomprehensive language and in forms that could not be easily accessed by citizens. Researchers, policy-makers, and benefactors have acknowledged the importance of an upright governance for the country's development in recent years. This has been reflected in empirical studies that have endeavored to explain the difference in development between countries because of institutional parties.

According to the survey of the IDM, $63 \%$ of the sampled citizens believed that public hearings were the only formal process and that their opinions are not considered. There were $47 \%$ that believed officials were irresponsible and not transparent in their decisions. The focus-group respondents believed that the political leaders had pre-determined agendas in accordance with their personal and often clientelistic interests; that politics affected 66\% of court decisions; and there was no such practice as accountability in their government, both on a central and a local level. Although $62 \%$ of sample citizens had the necessary information and expertise to decide and judge whether the proposed policy was beneficial for them or not, they permit the Parliament to make decisions for them and this encouraged social apathy. There were $79 \%$ of the sample citizens that considered that the Parliament should force the government be accountable. The focus-group respondents considered benefactors as another party that influences the governmental performance. They donate funds and have significant power to control how the funds are used. Since institutions intermittently have the need for funding, they will be obligated to perform accordingly. There were $71 \%$ of sample citizens who believed that it was possible for the government to improve. Their trust relied on Albania moving a step forward each time international institutions or strong diplomatic representations pressured or presented recommendations.

In regards to the institutional performance, according to the IDM survey, 50\% of the sample citizens evaluated positively, or within a scale of 3 to 5 , the government's performance. According to the focus-group respondents, citizens viewed the government as relatively inefficient because it offered low quality services and progression was small and slow. The weakest score was allocated to the 
performance of justice institutions, with $44 \%$ trust award by the citizens that participated in the IDM survey. The service institutions and their associated services had the lowest evaluation according to the IDM opinion poll. The least of those evaluated was employment, with $51 \%$ trust awarded. According to the IDM survey, up to $42 \%$ of sampled citizens were trusting of the education service. According to the focus-groups respondents, the score was medium. At least, education did not cause major concern, and students today have the chance to obtain qualifications in an 'open' Albania. Possibly, citizens in Albania are less affected by the quality of education because they are more extended in time. Institutions that have closer relations with citizens are the ones in which they trust less.

\section{Conclusions}

Public trust in the government is an important factor in helping institutions move forward with reforms and it raises the level of governmental performance. The citizens' low trust in Albanian public institutions was related to a lack of transparency in institutions, the exclusion of citizens as part of the decision-making, and a result of offering low quality services. The evaluation of the political parties, as being less reliable than institutions, suggested a dominance of clientelism and nepotism in the governmental sphere and lack of party connection with the electorate, who represent society. Also, evaluating the judicial system, as less reliable than the other systems, indicated a lack of guarantee to adjust the public institutions' performance, the lack of a system able to offer quality service, and that its citizens, who do not accept this system as a fair one, may substitute it with an alternative form. The measured indicators showed the 'domino effect' that associates with poor results in terms of the mutual relationship that exists between governments and citizens.

\section{References}

Adler, P., \& Kwon, S. (2000). Social capital: The good, the bad and the ugly. In E. Lesser (Ed.). Knowledge and Social Capital: Foundations and Applications. Butterworth-Heinemann.

Elster, J. (1989). The Cement of Society. A Survey of Social Order, Columbia University, New York.

Baker, W. (2000). Achieving Success through Social Capital: Tapping Hidden Resources in Your Personal and Business Networks, University of Michigan Business School Series.

Bellova, O. (2014). The performance of public sector and its impact in economic growth. Doctoral thesis, Faculty of Economics, University of Tirana.

Bourdieu, P. (1986) in J. Richardson, ed. Handbook of Theory and Research for the Sociology of Education. Westport, CT: Greenwood Press. The forms of capital.

Coleman, J. S. (1988). Social capital in the creation of human capital. The American Journal of Sociology, 94(Supplement): S95-S120.

Coleman, J. (1990). Foundations of Social Theory. Cambridge, Mass: Harvard University Press.

Dasgupta, P. (1988). Trust as a commodity. In D. Gambetta (Ed.). Trust: Making and Breaking Cooperative Relations. Oxford, Blackwell.

Dasgupta, P. (2000). Economic progress and the ideal of social capital. In P. Dasgupta, \& I. Serageldin. (Ed). Social Capital: A Multifaceted Perspective. The World Bank.

Easton, D. (1965). A System Analysis of Political Life. Wiley \& Sons, Inc, New York, United States.

Farrell, H., \& Knight, J. (2003). Trust, institutions, and institutional change: Industrial districts and the social capital hypothesis. Politics \& Society, 31(4): 537-566.

Freedom House (2015). Nations in Transit. Accessed on 04-10-2016 https://freedomhouse.org/report/nationstransit/2015/albania

Field, J. (2003). Social Capital. NY: Routledge.

Fu, Q, (2004) Trust, Social Capital, and Organizational Effectiveness. The Faculty of the Virginia Polytechnic Institute and State University. Available from: http://www.ipg.vt.edu/papers/qhfumajorpper.pdf

Fukuyama. F, (1999). Social Capital and Civil Society. The Institute of Public Policy, George Mason University, Prepared for delivery at the IMF Conference on Second Generation Reforms. Retrieved on 04.12.2016 from https://www.imf.org/external/pubs/ft/seminar/1999/reforms/fukuyama.htm

Fukuyama, F. (1995). Trust: Social Virtues and the Creation of Prosperity. NY: Free Press.

Gambetta, D. (1988). Trust: Making and Breaking Cooperative Relations. Oxford, Blackwell. 
Granovetter, M. (1985). Economic action and social structure: The problem of embeddedness. American Journal of Sociology, 91: 481-510.

Luhmann, N. (1988). 'Familiarity, Confidence, Trust: Problems and Alternatives', in Diego Gambetta (ed.) Trust: Making and Breaking of Cooperative Relations. Oxford: Blackwell, 94-107.

Lame, E., \& Papa, A. (2015). Opinion Poll: Trust in government, IDM, Albania.

Levi, M. (1996). Social and unsocial capital: A review essay of Robert Putnam's Making Democracy Work. Politics and Society, 24: 46-55.

McCauley, D., \& Kuhnert, K. (1992). A theoretical review and empirical investigation of employee trust in management. Public Administration Quarterly, 265-284.

Misztal, B. A. (1996) Trust in Modern Societies: The Search for the Bases of Social Order (Cambridge: Polity Press).

Nahapiet, J., \& Ghoshal, S. (1998). Social capital, intellectual capital, and the organizational advantage. The Academy of Management Review, 23(2): 242-267.

North, D. C. (1990). Institutions, Institutional Change and Economic Performance. New York: Cambridge University Press, p. 41.

OECD. (n.d.). Trust in Government. Retrieved from http://www.oecd.org/gov/trust-in-government.htm

Putnam, R. (1993). Making democracy work: civic tradition in modern Italy. Princeton: Princeton University Press.

Putnam, R. (1995). Tuning in, tuning out: The strange disappearance of social capital in America. Political Science and Politics, 28(4): 664-683.

Williams, B. (1988). Formal structures and social reality. In Gambetta, D.(Ed). Trust: Making and Breaking Cooperative Relations. Oxford, Blackwell.

Wolfe, R. N. (1976). Trust, anomie, and the locus of control: alienation of US college student in 1964, 1969, 1974. Journal of Social Psychology, 100: 151-172.

Woolcock, M. (1998). Social capital and economic development: Toward a theoretical synthesis and policy framework. Theory and Society, 27(2): 151-208. 